\title{
Studies on Carbohydrate-Metabolizing Enzymes
}

\author{
8. THE ACTION OF Z-ENZYME ON GLYCOGEN-TYPE POLYSACCHARIDES*
}

\author{
By W. L. CUNNINGHAM, D. J. MANNERS AND A. WRIGHT \\ Department of Chemistry, University of Edinburgh
}

(Received 28 May 1962)

The action of Z-enzyme on amylose consists of the random hydrolysis of a small number of $\alpha-(1 \rightarrow 4)$-glucosidic linkages causing an increase in $\beta$-amylolysis limit and a decrease in limiting viscosity number and iodine-staining power (Cunningham, Manners, Wright \& Fleming, 1960; Banks, Greenwood \& Jones, 1960). With amylopectin, small increases in $\beta$-amylolysis limit have been noted (Cunningham et al. 1960), and with amylopectin $\beta$-dextrin, a marked decrease in turbidity occurs (Banks et al. 1960). However, the concentration of $Z$-enzyme impurity in many amorphous preparations of $\beta$-amylase is so low that, when the $\beta$-amylase activity has been selectively inhibited, it does not produce measurable changes in the iodine-staining power of amylose (Cunningham et al. 1960). Such preparations show little or no amylolytic activity towards glycogen (Banks et al. 1960) and it has been suggested that this property differentiates Z-enzyme from other $\alpha$ amylases. In our previous paper (Cunningham et al. 1960) an alternative possibility was expressed, namely, that the apparent failure of $Z$-enzyme to attack glycogen was partly due to the low enzyme concentration; we now describe the experimental evidence for this view.

The samples of Z-enzyme used previously were 'stock' soya-bean $\beta$-amylase, almond emulsin and a commercial (Wallerstein) barley $\beta$-amylase preparation. Since $\mathrm{Z}$-enzyme had the properties of an $\alpha$-amylase, and was stabilized by $\mathrm{Ca}^{2+}$ ions, flour from these sources has been extracted with $0.2 \%$ calcium chloride solution, and the $\alpha$-amylolytic activity of the extracts examined.

\section{METHODS AND MATERIALS}

Analytical methods. The methods used for paper chromatography, iodine staining of polysaccharides and the determination of reducing sugars have been described by Gunja, Manners \& Khin Maung $(1960,1961)$. Protein N was determined by the method of Robinson \& Hogden (1940). The turbidity of polysaccharide solutions was measured with a Unicam SP. 600 spectrophotometer at $420 \mathrm{~m} \mu$ with $1 \mathrm{~cm}$. cells against a water blank. $\alpha$-Amylase and $\beta$-amylase activities were assayed by the methods of

\footnotetext{
* Part 7: Gunja, Manners \& Khin Maung (1961).
}

Fischer \& Stein (1954) and Hobson, Whelan \& Peat (1950) respectively, and the units of activity were those defined by these workers.

Electrophoresis. A Shandon continuous-curtain apparatus was used, with sheets of Whatman no. 54 filter paper and $0.05 \mathrm{M}$-sodium phosphate buffer, $\mathrm{pH} 6 \cdot 9$. Operating conditions were $900 \mathrm{v}, 10 \mathrm{~mA}$, at $0^{\circ}$. Distribution of the protein was determined by heating the sheet of filter paper at $100^{\circ}$ for $10 \mathrm{~min}$., and staining the denatured protein with nigrosine solution ( $1 \%$ in $2 \%, v / v$, acetic acid) as described by Scardi \& Bonavita (1958).

Substrates. Samples of potato amylose and $\beta$-dextrin, waxy-maize starch and $\beta$-dextrin, and glycogen $\beta$-dextrin were as described by Cunningham et al. (1960). Humanliver glycogen was the sample A.K. reported by Calderbank, Kent, Lorber, Manners \& Wright (1960). Rabbit-muscle and pig-liver glycogens were laboratory preparations.

Enzyme preparations. Wallerstein 'Analytical grade' barley $\beta$-amylase and 'stock' soya-bean $\beta$-amylase were the preparations described by Cunningham et al. (1960). Ungerminated barley (var. Ymer) was kindly supplied by W. Younger and Co. Ltd., Edinburgh.

Almond-emulsin preparations. Emulsin was prepared from sweet almonds by the method of Tauber (1932). Sweet almonds (1 kg.) were soaked in water overnight, the skins removed and then the almonds were minced, defatted with ether and dried at room temperature. Yield, $335 \mathrm{~g}$. The powder $(200 \mathrm{~g}$.) was extracted with $1600 \mathrm{ml}$. of aqueous $33 \%(\mathrm{v} / \mathrm{v})$ ethanol for $10 \mathrm{~min}$. at $20^{\circ}$, the mixture filtered, and the residue dried with acetone and ether, giving $185 \mathrm{~g}$. of crude almond powder. The filtrate was cooled to $0^{\circ}$ and the precipitate that formed was discarded before addition of $800 \mathrm{ml}$. of $95 \%(\mathrm{v} / \mathrm{v})$ ethanol. After being centrifuged, the precipitate was dissolved in water and dialysed for $18 \mathrm{hr}$. at $0^{\circ}$ against running tap water before freeze-drying. Yield of emulsin (fraction P), 5.0 g., $\alpha$-amylase activity 0.002 unit/mg. $(0.017 \mathrm{unit} / \mathrm{mg}$. of protein $\mathrm{N}$ ).

Crude almond powder $(60$ g.) was then extracted with $400 \mathrm{ml}$. of water at $20^{\circ}$ for $30 \mathrm{~min}$. The residue was discarded. The extract was cooled to $0^{\circ}$, the precipitate that formed being collected by centrifuging (fraction A). The solution was then fractionated at $0^{\circ}$ with ammonium sulphate, the protein precipitating at 0-33, 33-42, 42-51 and $51-100 \%$ saturation being collected (fractions B, C, D and $\mathbf{E}$ ), dissolved in a small quantity of water and dialysed at $0^{\circ}$ for $18 \mathrm{hr}$. before being freeze-dried. The yields of the five fractions were $50,400,2800,650$ and $400 \mathrm{mg}$. repectively, and the protein $\mathrm{N}$ contents $4 \cdot 6,12 \cdot 4,11 \cdot 9,7 \cdot 3$ and $11 \cdot 1 \%$.

Preparation of $\alpha$-amylase extracts. The general method of Kneen, Sandstedt \& Hollenbeck (1943) was used. Crude 
almond powder, barley flour or soya-bean flour (about 50 g.) was extracted with water $(5 \mathrm{ml} . / \mathrm{g}$.) at $\mathrm{pH} 5.2$ containing calcium chloride $(2 \mathrm{mg} . / \mathrm{ml}$.) for $1 \mathrm{hr}$. at room temperature $\left(18-20^{\circ}\right)$. After being centrifuged, the extracts were heated at $70^{\circ}$ for $15 \mathrm{~min}$. and cooled quickly to $20^{\circ}$. (This causes selective inactivation of any $\beta$-amylase.) The almond and barley extracts were then dialysed at $0^{\circ}$ for $30-48 \mathrm{hr}$. against running tap water, centrifuged and the supernatant solutions freeze-dried. The soya-bean extract was centrifuged, and $50 \mathrm{~mm}$ - $p$-chloromercuribenzoate solution ( $2 \mathrm{ml}$.) added. After dialysis overnight, the extract was finally freeze-dried. The yields and $\alpha$-amylase activities of the preparations were: almond, $6.5 \mathrm{~g}$. (0.0039 unit/mg.); barley, $0.9 \mathrm{~g}$. (0.005 unit/mg.); soya bean, $2.0 \mathrm{~g}$. (0.006 unit/mg.).

Preparation of enzyme solutions. Weighed amounts of the various enzyme preparations were mixed with water or buffer, centrifuged and insoluble material was discarded. Unless otherwise stated, $0 \cdot 2 \mathrm{M}$-sodium acetate buffer, pH 5.6, was used.

\section{RESULTS}

\section{Properties of barley $\alpha$-amylase}

Effect of $\mathrm{pH}$ and various inhibitors. In $0.06 \mathrm{M}-$ sodium phosphate-0.03 M-citrate buffer, $\mathrm{pH} 4 \cdot 1$ $7 \cdot 1, \alpha$-amylase activity was optimum at $\mathrm{pH} 5 \cdot 2-5 \cdot 6$, as determined by measurement of the decrease in iodine-staining power of soluble starch. An $\alpha$ amylase preparation from a germinated sample of the same variety of barley had a similar optimum $\mathrm{pH}$.

In the presence of $0.1,0.01$ and $0.001 \mathrm{~mm}$ mercuric chloride, the activity after 1 and $2 \mathrm{hr}$. was inhibited by 88,81 and $13 \%$ respectively. Preincubation of the enzyme preparation with these concentrations of mercuric chloride for $3 \mathrm{hr}$. at $37^{\circ}$ before addition of the substrate resulted in complete inactivation.

The effect of $\mathrm{Ca}^{2+}$ ions and EDTA was examined by incubation of the barley preparation $(0 \cdot 1 \%$ in water, $4 \mathrm{ml}$.) at $37^{\circ}$ with buffer, $\mathrm{pH} 5.6(5 \mathrm{ml}$.$) , and$ (a) water ( $1 \mathrm{ml}$.), (b) $3 \mathrm{~mm}$-calcium acetate solution (1 ml.) or (c) $3 \mathrm{~mm}$-EDTA solution (1 ml.) for $3 \mathrm{hr}$. Rabbit-muscle glycogen (18 mg. in $20 \mathrm{ml}$. of water) was then added. After $20 \mathrm{hr}$. at $37^{\circ}$ the apparent percentage conversions into maltose were $(a) 6$, (b) 8 and (c) 0 , and the percentage decreases in extinction at $480 \mathrm{~m} \mu$ of the iodine complexes were (a) 44, (b) 50 and $(c) 0$.

Tests for other carbohydrases. Digests containing cellobiose, laminarin or maltose $(10 \mathrm{mg}$. in $0.5 \mathrm{ml}$. of buffer, $\mathrm{pH} 5 \cdot 6)$ and barley preparation $(5 \mathrm{mg}$. in $0.5 \mathrm{ml}$. of water) were incubated at $37^{\circ}$ for $24 \mathrm{hr}$. Paper-chromatographic analysis showed the absence of glucose in all digests, indicating the absence of cellobiase, laminarinase and maltase from the enzyme preparation.

Action of low concentrations on glycogen and amylopectin. Digests were prepared from human-liver glycogen or waxy-maize starch (about $200 \mathrm{mg}$.), buffer, pH 5.6 (15 ml.), barley preparation (1 mg.) and water (to $50 \mathrm{ml}$.). Samples $(15 \mathrm{ml}$.) were removed at intervals, the $\alpha$-amylase was inactivated by heating $\left(5 \mathrm{~min}\right.$. at $\left.98^{\circ}\right)$, the $\mathrm{pH}$ adjusted to 3.6 with acetic acid, and the $\beta$-amylolysis limit then determined. With waxy-maize starch, the $\beta$-amylolysis limits were 57,62 and $62 \%$ respectively after incubation for 0,6 and $22 \mathrm{hr}$. at $25^{\circ}$ with the $\alpha$-amylase, and for glycogen, 46,47 and $48 \%$.

Action of low concentrations on $\beta$-dextrins. $\beta$ Dextrins of amylose $(6.0 \mathrm{mg}$.$) , amylopectin$ (15.6 mg.) and glycogen (19.0 mg.), buffer, pH 5.6 $(5 \mathrm{ml}),. \alpha$-amylase preparation $(0.5 \mathrm{mg}$.) and water (to $30 \mathrm{ml}$.) were incubated at $37^{\circ}$. The decrease in extinction of the amylose $\beta$-dextrin-iodine complex at $680 \mathrm{~m} \mu$ was 17,23 and $26 \%$ after 7,25 and $47 \mathrm{hr}$., and with the amylopectin $\beta$-dextrin-iodine complex, the extinction at $540 \mathrm{~m} \mu$ fell by 8,12 and $14 \%$. There was no significant change in the reducing power of the three digests, nor in the iodinestaining power of glycogen $\beta$-dextrin.

Action of high concentrations on glycogen. Glycogen was incubated with barley $\alpha$-amylase in the presence and absence of $5 \mu \mathrm{M}-p$-chloromercuribenzoate ( $\beta$-amylase inhibitor). As shown in Table 1 , there was a rapid fall in iodine-staining power and a slow production of reducing sugars. Since $p$-chloromercuribenzoate had no effect on the reaction, the activity is not due to $\beta$-amylase impurity.

The turbidity of glycogen and glycogen $\beta$-dextrin is also reduced by barley $\alpha$-amylase. Pig-liver glycogen or $\beta$-dextrin (about $25 \mathrm{mg}$.) was dissolved in $0.5 \%$ sodium chloride solution $(5 \mathrm{ml}$.$) ; barley$ $\alpha$-amylase (62 mg.) was suspended in $0.2 \mathrm{M}$-sodium

\section{Table 1. Action of barley preparation on glycogen}

Digests containing rabbit-muscle glycogen (45 mg.), buffer, pH 5.6 (20 ml.), $\alpha$-amylase preparation [18 mg. in $10 \mathrm{ml}$. of water or $25 \mu \mathrm{M}$ - $p$-chloromercuribenzoate (pCMB)] in a total volume of $50 \mathrm{ml}$. were incubated at $25^{\circ}$. Samples were removed for measurement of iodine-staining power and the production of reducing sugars (expressed as $P_{\mathrm{M}}$, apparent percentage conversion into maltose).

\begin{tabular}{|c|c|c|c|c|}
\hline \multirow{2}{*}{$\begin{array}{l}\text { Time of } \\
\text { incubation } \\
\text { (hr.) }\end{array}$} & \multicolumn{2}{|c|}{ Without pCMB } & \multicolumn{2}{|c|}{ With pCMB } \\
\hline & $\begin{array}{c}E_{480 \mathrm{~m} \mu} \\
(\%)\end{array}$ & $P_{\mathbf{M}}$ & $\begin{array}{c}E_{480 \mathrm{~m} \mu} \\
(\%)\end{array}$ & $P_{\mathbf{M}}$ \\
\hline 0 & 100 & - & 100 & - \\
\hline 1 & 75 & 1 & 77 & 1 \\
\hline 2 & 54 & - & 59 & - \\
\hline 3 & 45 & - & 49 & - \\
\hline 4 & 41 & 5 & 38 & 5 \\
\hline 7 & - & - & 27 & 6 \\
\hline 23 & 7 & - & - & - \\
\hline 24 & - & 7 & 5 & 7 \\
\hline
\end{tabular}


acetate buffer, $\mathrm{pH} 5 \cdot 2$, containing $0.01 \mathrm{M}$-calcium acetate $(12 \mathrm{ml}$.). Solutions of substrate $(5 \mathrm{ml}$.) and enzyme (5 ml.) were mixed, filtered (G-3 sintered glass) and the extinction at $420 \mathrm{~m} \mu$ was measured at intervals. With pig-liver glycogen the extinctions after $5 \mathrm{~min}$., 16 and $24 \mathrm{hr}$. were $0.487,0.268$ and 0.205 , and with the $\beta$-dextrin, $0.305,0.173$ and $0 \cdot 150$. These results correspond to 58 and $51 \%$ decreases in turbidity during $24 \mathrm{hr}$., and the apparent percentage conversion into maltose was 23 and $17 \%$, respectively.

\section{Studies on the Wallerstein preparation of $\beta$-amylase}

Effect of concentration on the $\beta$-amylolysis limit of glycogen. Liddle \& Manners (1957) have shown that variation of the enzyme concentration within the range 40-100 units of $\beta$-amylase/mg. of glycogen does not significantly alter the $\beta$-amylolysis limit. The enzyme concentration has now been increased further. In digests at $\mathrm{pH} \mathrm{5.6}$ containing 50, 250 and 500 units of $\beta$-amylase $/ \mathrm{mg}$. of glycogen, the $\beta$-amylolysis limits were 45,52 and $57 \%$. This significant increase is further evidence for the presence of a trace of $\alpha$-amylase in the commercial enzyme preparation.

Electrophoresis studies. The enzyme preparation (2.0 g.; 220000 units; $0.47 \%$ protein N) was dialysed against several changes of distilled water at $0^{\circ}$ for $72 \mathrm{hr}$. The resulting solution was freezedried to give a white amorphous powder (180 mg.; 43200 units; $6 \cdot 43 \%$ protein N). This material (20 mg.) was dissolved in $1.5 \mathrm{ml}$. of $0.05 \mathrm{M}$-sodium phosphate buffer, $\mathrm{pH} 6.9$, and applied to the filterpaper curtain. After $18 \mathrm{hr}$., the curtain was developed with nigrosine; three bands of protein were revealed, one travelling towards the cathode (fractions 20 and 21), one moving vertically downwards (fractions 23 and 24) and the other migrating towards the anode (fraction 25). Each fraction was diluted to $7 \mathrm{ml}$. and assayed for $\beta$-amylase activity
(Table 2). The presence of Z-enzyme ( $\alpha$-amylase) was shown by measurement of the change in iodinestaining power of amylose $\beta$-dextrin. $\beta$-Amylase alone has no effect, but, when it acts in conjunction with $\alpha$-amylase, a rapid fall in iodine-staining power should occur. Amylose $\beta$-dextrin (3.2 mg.), fractions 21-25 (1 ml.) in a total volume of $5 \mathrm{ml}$., was incubated at $37^{\circ}$ for $20 \mathrm{hr}$. The decrease in extinction of the polysaccharide-iodine complex at $600 \mathrm{~m} \mu$ is shown in Table 2. Fractions 21 and 22 were found to be free from $\alpha$-amylase.

To differentiate between $\beta$-amylase and $\mathrm{Z}$ enzyme action, similar digests were incubated in the presence of $10 \mu \mathrm{M}$ - $p$-chloromercuribenzoate. The results (Table 2) show that the Z-enzyme activity occurs mainly in fractions 24 and 25 and $\beta$-amylase activity is concentrated in fraction 23.

These results were confirmed by incubation of fractions 23-25 with amylopectin and glycogen $\beta$-dextrin. Digests containing amylopectin $\beta$ dextrin $(20 \mathrm{mg}$. in $10 \mathrm{ml}$. of water) or glycogen $\beta$-dextrin (12 mg. in $4 \mathrm{ml}$. of water), $0.2 \mathrm{M}$-sodium acetate buffer, pH 4.6 ( $5 \mathrm{ml}$.), and fraction ( $1 \mathrm{ml}$. were incubated at $37^{\circ}$. The results (Table 2) show clearly that fraction 24 has the highest $\alpha$-amylase activity.

\section{Properties of soya-bean $\alpha$-amylase}

Although in sodium acetate buffer $\alpha$-amylase activity was optimum in the range $\mathrm{pH} 6 \cdot 7-7 \cdot 0$, digests were made at $\mathrm{pH} 5 \cdot 6$, as in the earlier experiments of Cunningham et al. (1960). $\beta$ Dextrins of amylose, amylopectin and glycogen were incubated with soya-bean $\alpha$-amylase. Reducing sugars were produced in all cases (Table 3), the extent of hydrolysis being inversely related to the degree of branching of the substrate. The same enzyme preparation also caused a marked decrease in the iodine-staining power of glycogen (Table 4).

In a further experiment, glycogen $\beta$-dextrin (50 mg.) was incubated with buffer, $\mathrm{pH} 5 \cdot 6$ $(10 \mathrm{ml}$.$) , and \alpha$-amylase preparation (90 mg.) in a

Table 2. Activity of fractions obtained by continuous electrophoresis

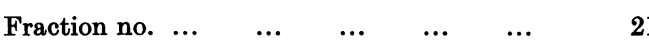

$\beta$-Amylase (total units)

21

22

23

24

14

63

1295

147

complex (\%)

(a) without pCMB

(b) with pCMB

Decrease in $E$ of amylopectin $\beta$-dextrin-iodine complex (\%)

(a) after $22 \mathrm{hr}$.

(b) after $44 \mathrm{hr}$.

Corresponding percentage conversion into maltose

(a) after $22 \mathrm{hr}$.

(b) after $44 \mathrm{hr}$.

Percentage conversion of glycogen $\beta$-dextrin into maltose after $144 \mathrm{hr}$.

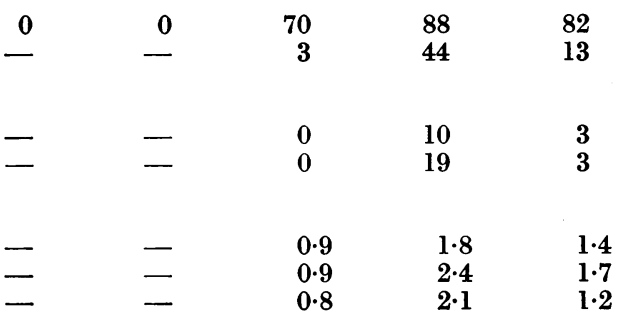

25

7

82

3

3 
Table 3. Production of reducing sugars from $\beta$-dextrins by soya-bean $\alpha$-amylase

The digests contained about $20 \mathrm{mg}$. of $\beta$-dextrin, enzyme solution before freeze-drying ( $1 \mathrm{ml}$.), buffer, $\mathrm{pH} 5 \cdot 6$ (5 ml.), and water to $20 \mathrm{ml}$. The production of reducing sugars is expressed as $P_{M}$, as in Table 1 .

Time of incubation (hr.)
Substrate
Amylose $\beta$-dextrin
Amylopectin $\beta$-dextrin
Glycogen $\beta$-dextrin

$\begin{array}{rr}22 & 47 \\ 81 & \\ 27 & 36 \\ 1 & \end{array}$

47
-36
4

70
100
38
6

$\begin{array}{rr}94 & 116 \\ 103 & 106 \\ 38 & 37 \\ 6 & 6\end{array}$

Table 4. Action of soya-bean $\alpha$-amylase on glycogen

Rabbit-muscle glycogen (50 mg.), buffer, pH 5.6 (20 ml.), and enzyme solution (5 ml.) were incubated at $37^{\circ}$.

\begin{tabular}{|c|c|c|c|c|c|c|}
\hline Time of incubation (hr.) $\quad \ldots \quad \quad \ldots$ & $1 \cdot 25$ & 2 & $2 \cdot 25$ & $\mathbf{3 \cdot 5}$ & 6 & 29 \\
\hline $\begin{array}{l}\text { Decrease in } E \text { of iodine complex at } \\
480 \mathrm{~m} \mu(\%)\end{array}$ & 18 & 23 & 35 & 39 & 52 & - \\
\hline Apparent conversion into maltose $(\%)$ & - & 6 & 9 & 14 & 18 & 26 \\
\hline
\end{tabular}

Table 5. Action of emulsin on amylose

Amylose (2 mg.), buffer, pH 5.6 (5 ml.), emulsin (8$20 \mathrm{mg}$.) and water $\left(4 \mathrm{ml}\right.$.) were incubated at $37^{\circ}$. Samples $\left(2 \mathrm{ml}\right.$.) were removed at intervals, heated $\left(5 \mathrm{~min}\right.$. at $\left.98^{\circ}\right)$, coagulated protein was removed and portions $(1 \mathrm{ml}$.) were stained with iodine solution.

\begin{tabular}{crrrr} 
& \multicolumn{4}{c}{ Decrease in $E$ at $680 \mathrm{~m} \mu(\%)$} \\
\cline { 2 - 5 } $\begin{array}{c}\text { Interval (hr.) } \ldots \\
\text { Concn. of enzyme } \\
\text { (mg./mg. of amylose) }\end{array}$ & & & & \\
4 & 8 & 11 & 20 & 27 \\
6 & 14 & 19 & 35 & 41 \\
8 & 20 & 26 & 45 & 52 \\
10 & 30 & 36 & 55 & 64 \\
\hline
\end{tabular}

total volume of $20 \mathrm{ml}$. The apparent percentage conversion into maltose after incubation at $37^{\circ}$ for 17,45 and $64 \mathrm{hr}$., was 7,13 and 16 .

These experiments show that both glycogen and its $\beta$-dextrin are substrates for soya-bean $\alpha$ amylase.

\section{Properties of almond-emulsin $\alpha$-amylase}

Effect of enzyme concentration. Preliminary experiments showed that the emulsin preparation (fraction $P$ ) contained salicinase and a trace of $\alpha$-amylase. The latter caused a decrease in the iodine-staining power of amylose, the extent of which depended on the concentration of the emulsin (Table 5). The $\alpha$-amylase was more stable than the salicinase at $20^{\circ}$.

Action on glycogen. Incubation of emulsin (fraction $\mathrm{P}$ ) with glycogen caused a fall in iodinestaining power and a limited production of reducing sugars. These changes were increased on pretreatment of the enzyme with calcium acetate, and decreased in the presence of EDTA (Table 6). The $\alpha$-amylolysis of glycogen, like that of amylose
(Cunningham et al. 1960), is dependent on the presence of $\mathrm{Ca}^{2+}$ ions.

$\alpha$-Amylase activity of fractions $B-E$. Since the unfractionated emulsin causes a reduction in the iodine-staining power of amylose (Table 5), the various fractions have been similarly examined. After incubation for $18 \mathrm{hr}$., the percentage decreases in the iodine-staining power of amylose were: B, 65; C, 51; D, 98; E, 77. By the method of Fischer \& Stein (1954), fractions $D$ and $E$ contained 0.0030 and 0.0047 unit/mg., equivalent to 0.041 and 0.042 unit/mg. of protein N. Fractions B and $\mathrm{C}$ could not be assayed under these conditions (incubation for $1 \mathrm{hr}$.), but their activity was much lower than that of $\mathbf{D}$ and $\mathbf{E}$ since, on incubation for $43 \mathrm{hr}$., the apparent production of maltose per mg. of fraction was: $\mathrm{B}, 0.09 ; \mathrm{C}, 0.07$; D, 0.55; E, 0.63.

Pig-liver glycogen $\beta$-dextrin $(40 \mathrm{mg}$. in $5 \mathrm{ml}$. of $0.5 \%$ sodium chloride solution) was mixed with a suspension of fraction D $(40 \mathrm{mg}$. in $5 \mathrm{ml}$. of $0.2 \mathrm{M}-$ sodium acetate buffer, $\mathrm{pH} 5 \cdot 2$, containing $0.01 \mathrm{M}$ calcium acetate). After filtration (G-3 sintered glass), the extinction at $420 \mathrm{~m} \mu$ after $10 \mathrm{~min} ., 6,24$ and $48 \mathrm{hr}$. was $0.508,0.480,0.285$ and 0.258 , equivalent to a $49 \%$ decrease in turbidity during $48 \mathrm{hr}$.; the apparent percentage conversion into maltose was $13 \%$. In a similar digest with $35 \mathrm{mg}$. of $\beta$-dextrin and $20 \mathrm{mg}$. of fraction $E$, the extinctions after $10 \mathrm{~min} ., 8$ and $24 \mathrm{hr}$. were 0.380 , 0.245 and $0.212(48 \%$ decrease in turbidity in $24 \mathrm{hr}$.) and the production of reducing sugar was $12 \%$. The turbidity measurements show that almond $\alpha$-amylase causes random hydrolysis of glycogen $\beta$-dextrin.

\section{Effect of complexones on Z-enzyme activity}

Since the $\mathbf{Z}$-enzyme or $\alpha$-amylase activity is stabilized by $\mathrm{Ca}^{2+}$ ions, we decided to compare the effect on the enzymic activity of two calcium- 
Table 6. Action of emulsin on glycogen

Emulsin solution (fraction P, $0.5 \% ; 4 \mathrm{ml}$.) was pretreated with $(a)$ water $(1 \mathrm{ml}$.$) , (b)$ calcium acetate or $(c)$ EDTA solution ( $b$ and $c, 1 \mathrm{ml}$; f final digest concentration, $0 \cdot 1 \mathrm{~mm}$ ) at $20^{\circ}$ for $15 \mathrm{~min}$. before addition to glycogen (24 mg.) in $25 \mathrm{ml}$. of buffer, $\mathrm{pH} 5 \cdot 6$.

Time of incubation (hr.) $\quad \ldots$

\begin{tabular}{|c|c|c|}
\hline \multicolumn{3}{|c|}{$\begin{array}{l}\text { Decrease in } E \text { at } \\
480 \mathrm{~m} \mu(\%)\end{array}$} \\
\hline 3 & 24 & 49 \\
\hline $\begin{array}{l}4 \\
8\end{array}$ & $\begin{array}{l}14 \\
28\end{array}$ & $\begin{array}{l}18 \\
36\end{array}$ \\
\hline 0 & 3 & 6 \\
\hline
\end{tabular}

$\overbrace{24}^{\begin{array}{c}\text { Apparent conversion } \\ \text { into maltose (\%) }\end{array}} \begin{array}{ll}2 \cdot 1 & 49 \\ 2 \cdot 6 & 3 \cdot 8 \\ 0 & 4 \cdot 4 \\ & 0.9\end{array}$

Table 7. Effect of complexones on $\alpha$-amylase activity

Digests contained amylopectin $\beta$-dextrin (10 mg.), barley $\beta$-amylase, 'stock' soya-bean $\beta$-amylase or soyabean $\alpha$-amylase, $20 \mathrm{mM}$-complexone [EDTA or trans-1,2-diaminocyclohexane- $N N N^{\prime} N$ '-tetra-acetic acid

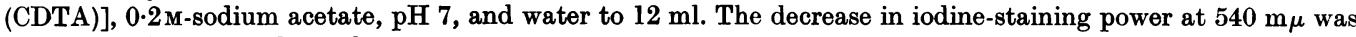
measured after 3.5 and $5.75 \mathrm{hr}$.

\begin{tabular}{|c|c|}
\hline $\begin{array}{l}\text { Time of } \\
\text { incubation } \\
(\mathrm{hr} .)\end{array}$ & Digest \\
\hline $3 \cdot 5$ & $\begin{array}{l}\text { Control } \\
\text { EDTA } \\
\text { CDTA }\end{array}$ \\
\hline $5 \cdot 75$ & $\begin{array}{l}\text { Control } \\
\text { EDTA } \\
\text { CDTA }\end{array}$ \\
\hline
\end{tabular}

\begin{tabular}{|c|c|c|}
\hline \multicolumn{3}{|c|}{ Enzyme preparation } \\
\hline $\begin{array}{c}\text { Barley } \\
\beta \text {-amylase }\end{array}$ & $\begin{array}{c}\text { 'Stock' } \\
\text { soya-bean } \\
\beta \text {-amylase }\end{array}$ & $\begin{array}{l}\text { Soya-bean } \\
\alpha \text {-amylase }\end{array}$ \\
\hline 11 & 73 & 85 \\
\hline 2 & 0 & 1 \\
\hline 1 & 0 & 0 \\
\hline 20 & 89 & 95 \\
\hline 13 & 7 & - \\
\hline 10 & 7 & 0 \\
\hline
\end{tabular}

chelating agents of the complexone type, EDTA and trans-1,2-diaminocyclohexane- $N N N^{\prime} N^{\prime}$-tetraacetic acid, kindly supplied by $\mathrm{Dr} T$. S. West (compare West, 1959). The results (Table 7) show that the $\alpha$-amylolytic activity is inhibited when calcium is removed from the enzyme preparations.

\section{DISCUSSION}

Our previous work (Cunningham et al. 1960) showed that the Z-enzyme impurity in a commercial sample of barley $\beta$-amylase was a trace of $\alpha$ amylase. Further examination of this enzyme preparation has provided additional evidence. Firstly, when very high concentrations (about ten times normal) are used, the $\beta$-amylolysis limit of glycogen is increased by over $10 \%$, indicating that some interior chains have been hydrolysed and made available for $\beta$-amylolysis. Secondly, electrophoresis of the barley preparation has given an essential separation of the enzymes since, in the three most active fractions, the relative $\beta$-amylase and $\alpha$-amylase activities (units/ml.) were respectively 185 to 3,21 to 44 and 1 to 13 .

The Z-enzyme impurity showed optimum $\mathrm{pH}$ at about $5 \cdot 6$, was stabilized by $\mathrm{Ca}^{2+}$ ions, and partly inhibited by EDTA and mercuric chloride (Cunningham et al. 1960). Barley $\alpha$-amylase shows similar properties. Furthermore, like other $\alpha$ amylases, appropriate concentrations of barley $\alpha$-amylase slowly hydrolyse glycogen and glycogen $\beta$-limit dextrin, although the rate is lower than with less highly branched substrates. In contrast, low concentrations of the enzyme have only a limited effect on the $\beta$-amylolysis limits of amylopectin and glycogen and on the iodine-staining power of amylose and amylopectin $\beta$-dextrin.

The presence of amylolytic activity in soya-bean extracts has been known for many years (e.g. Street \& Bailey, 1915), but this is usually considered to be due only to $\beta$-amylase (Newton, Hixon \& Naylor, 1943). The results in Tables 3 and 4 show that soya beans do, in fact, contain small amounts of $\alpha$-amylase, which attacks the $\beta$ dextrins of the starch components and glycogen, and also cause random degradation of glycogen. The $\alpha$-amylase activity in soya-bean flour was of the same order as that in barley flour and in almond emulsin. Flour prepared from a different batch of soya beans, kindly provided by $\mathrm{Dr}$ C. T. Greenwood, also contained a similar trace of $\alpha$-amylase activity.

The present experiments also confirm the presence of a trace of $\alpha$-amylase in almond emulsin, in agreement with the results of Hopkins \& Bird (1953). The initial preparation contained only $0.017 \mathrm{unit} / \mathrm{mg}$. of protein nitrogen, but ammonium sulphate fractionation of crude almond powder gave preparations with a two- to three-fold increase in activity. The almond $\alpha$-amylase causes a 
decrease in the turbidity and iodine-staining power of glycogen-type polysaccharides, and its action is similar to that previously described for Z-enzyme on amylose $\beta$-dextrin in that it is increased by $\mathrm{Ca}^{2+}$ ions and decreased by EDTA.

\section{SUMMARY}

1. $\beta$-Amylase preparations from barley and soya beans, and $\beta$-glucosidase preparations from almond emulsin, show $\mathbf{Z}$-enzyme activity, which is due to the presence of a trace of $\alpha$-amylase. Extraction of the above-named plant materials with dilute calcium chloride solution has given preparations with $\alpha$-amylolytic activity.

2. The above-named plant $\alpha$-amylases attack glycogen and glycogen $\beta$-dextrin and are not therefore differentiated from normal $\alpha$-amylases.

3. The $\alpha$-amylase activity towards glycogen is increased by $\mathrm{Ca}^{2+}$ ions and decreased by complexones, thus resembling that of $\mathrm{Z}$-enzyme on amylose.

The authors are grateful to Professor E. L. Hirst, C.B.E., F.R.S., for his interest in this work, to Cand. real. O. Kjølberg for the turbidity measurements, to $\mathrm{Dr} H$. T. Macpherson for the loan of the electrophoresis apparatus, and to the Department of Scientific and Industrial Research for maintenance allowances (to W.L.C. and A.W.).

\section{REFERENCES}

Banks, W., Greenwood, C. T. \& Jones, I. G. (1960). J. chem. Soc. p. 150.

Calderbank, A., Kent, P. W., Lorber, J., Manners, D. J. \& Wright, A. (1960). Biochem. J. 74, 223.

Cunningham, W. L., Manners, D. J., Wright, A. \& Fleming, I. D. (1960). J. chem. Soc. p. 2602.

Fischer, E. H. \& Stein, E. A. (1954). Arch. Sci., Genève, 7, 131.

Gunja, Z. H., Manners, D. J. \& Khin Maung (1960). Biochem. J. 75, 441.

Gunja, Z. H., Manners, D. J. \& Khin Maung (1961). Biochem. J. 81, 392.

Hobson, P. N., Whelan, W. J. \& Peat, S. (1950). J. chem. Soc. p. 3566.

Hopkins, R. H. \& Bird, R. (1953). Nature, Lond., 172, 492.

Kneen, E., Sandstedt, R. M. \& Hollenbeck, C. M. (1943). Cereal Chem. 20, 399.

Liddle, A. M. \& Manners, D. J. (1957). J. chem. Soc. p. 3432.

Newton, J. M., Hixon, R. M. \& Naylor, N. M. (1943). Cereal chem. 20, 23.

Robinson, H. W. \& Hogden, C. G. (1940). J. biol. Chem. 135, 727.

Scardi, V. \& Bonavita, V. (1958). J. Chromat. 1, 287.

Street, J. P. \& Bailey, E. M. (1915). Industr. Engng Chem. 7, 853.

Tauber, H. (1932). J. biol. Chem. 99, 257.

West, T. S. (1959). Roy. Inst. Chem. Lect., Monogr. \& Rep. no. 1 , p. 11 .

Biochem. J. (1962) 85, 413

\title{
Comparative Studies of 'Bile Salts'
}

\section{BILE SALTS OF MONOTREMES AND OBSERVATIONS ON GLYCINE CONJUGATION*}

\author{
By R. J. BRIDGWATER, G. A. D. HASLEWOOD ANd A. R. TAMMAR \\ Guy's Hospital Medical School, London, S.E. 1
}

\section{(Received 21 June 1962)}

The egg-laying mammals, order Monotremata, which are represented as living forms only by the platypus (Ornithorhynchus anatinus) and the spiny anteaters (Tachyglossus and Zaglossus), have been the objects of intense study (Simpson, 1945). In spite of this, their relationships to marsupial and placental mammals are poorly understood and it has been suggested that they may have had a separate reptilian origin (see Romer, 1945). We now report on the bile salts of the platypus and of Tachyglossus (Echidna) aculeatus, the Australian spiny anteater.

\footnotetext{
* Part 15: Anderson \& Haslewood (1962).
}

Bile acids conjugated with glycine have been found only in mammals, and we have come to think that they may be confined to Eutheria. We have therefore applied improved methods for the detection of glycine conjugates to the bile salts of the monotremes mentioned above and of six species of marsupials.

\section{RESULTS}

The bile of the monotremes apparently contained only $\mathrm{C}_{24}$ bile acids, and chiefly cholic $(3 \alpha, 7 \alpha, 12 \alpha$ trihydroxycholanic) acid, with a small fraction 